\title{
Recombinant Monocyte Chemoattractant Protein-1
}

National Cancer Institute

\section{Source}

National Cancer Institute. Recombinant Monocyte Chemoattractant Protein-1. NCI

Thesaurus. Code C1393.

A recombinant therapeutic agent which is chemically identical to or similar to endogenous human monocyte chemoattractant protein-1, a member of the CC chemokine family which is chemotactic for monocytes. (NCI04) 